Türkiye'de Hastaya Gerçeğin Söylenmesi: Tıp Etiği Ve Tıp Hukuku Açısından

\title{
Telling The Truth To Patients In Turkey: In Terms Of Medical Ethics And Medical Law
}

\section{Gürkan Sert}

Marmara Üniversitesi Tıp Fakültesi, Tıp Tarihi ve Etik Anabilim Dalı, İstanbul, Türkiye

\section{ÖZET}

Hastanın zarar görmemesi ya da hastaya yarar sağlanması beklentisiyle hastaya sağllk durumu, tanısı, tedavisi ile ilgili bilgi verilmemesi ya da bunlar ile ilgili hastadan bilgi saklanması hekim-hasta ilişkisinin eski dönemlerinden beri vardır. Ancak bu uygulama hem uluslararası hasta hakları belgelerinde hem de yasalarca korunan hastanin bilgilendirilme, özel yaşamının korunması, geleceğini belirleme haklarının ihlaline neden olabilmektedir. Günümüzde bu gibi yaklaşımlardan uzaklaşılmakta olsa da hastaya sağlık durumu hakkında bilgi verilmemesi bazı kültürlerde yaygındır.

Türkiye'de hastanın zarar görmemesi amacıyla hastaya gerçeğin söylenmemesine olanak săglayan hükümler sağllk mevzuatında yer almaktadır. Tibbi Deontoloji Tüzüğü ve Hasta Hakları Yönetmeliği'nde hastaya sağllk durumu ile ilgili bilginin verilmesinin hastaya zarar verebileceği hallerde, bilginin hastadan saklanabileceği belirtilmiştir. Makalede bu hükümler, hastanın geleceği hakkinda karar verme, tıbbi girişime onam verme, özel hayatına sayg hakları açısından incelenmiş ve bu hükümlerin tıp hukuku ve etiğine uygun olarak yeniden düzenlenmeleri ile ilgili önerilere yer verilmiştir.

Anahtar Kelimeler: gerçeğin söylenmesi, tıp etiği, tıp hukuku, özerklik, gizlilik

\begin{abstract}
Since the ancient times of the physician-patient relationship, withholding information from the patient or keeping the patient in the dark about his health status, diagnosis or treatment in anticipation of benefiting or not harming the patient, exists. However, this practice may cause violations of the patient's right to be informed, right to privacy and right of selfdetermination, protected by both the law and the international patient rights documents. Today, even though such approaches are being abandoned, withholding information from the patient regarding his health status is still common in some cultures.

In Turkey, provisions that allow withholding the truth from the patient, in order to avoid harming the patient can be found in the health legislation. In the Medical Deontology Regulation and the Patient Rights Regulation; it is stated that, in cases, where it may harm the patient, the information about his health status can be hidden from the patient.

In this article, these provisions were examined in terms of the patient's right of self-determination, right to give consent to the medical intervention, right to respect for private life and some suggestions are included regarding the reorganization of these provisions in accordance with medical law and ethics.
\end{abstract}

Keywords: telling the truth, medical ethics, medical law, autonomy, privacy

\section{Iletişim / Correspondence:}

Dr. Gürkan Sert

Marmara Üniversitesi Tıp Fakültesi, Tıp Tarihi ve Etik Anabilim Dall, İstanbul, Türkiye

E-mail:drgurkansert@gmail.com

Başvuru Tarihi: 10.02.2020

Kabul Tarihi: 27.03.2020 


\section{GİRIŞ}

Hastanın sağlık durumu hakkında bilgilendirilme hakk1, hastanın sağlık durumu, kendisine gerçekleştirilecek tıbbi girişimler, bu girişimler ile ilgili seçenekler, bunların yararları, zararları, sonuçları hakkında bilgilendirilmesini kapsar. $\mathrm{Bu}$ hak hem uluslararası hasta hakları belgelerinde hem de yasalarda korunan bir hasta hakkıdır (1). Bilgilendirilme hakk1 ile hasta, kendisine gerçekleştirilecek tıbbi girişim hakkında bilgi sahibi olur, beden bütünlüğü ve geleceği hakkında serbest iradesi ile karar verebilir (2). Hastaya seçim yapabilecek, karar verebilecek bilgiler sunulmas1, hastanın yaşam tarzına göre daha az zarar göreceği veya daha çok yararlanabileceği tıbbi girişimi seçme olanağı da sağlar (1). Ancak hastanın zarar görmemesi ya da hastaya yarar sağlanmas1 beklentisiyle hastaya sağlık durumu ile ilgili bilgi verilmediği gibi eksik bilgi de verilebilmektedir $(3,4,5)$. Bilginin hastadan saklanmas1 ile hastanın depresyona girmemesi, travmatize olmamas1, tedavilere uyum göstermesi gibi beklentiler vardır (5).

Hastaya gerçeğin söylenmemesi özellikle hastanın özerklik hakkı bağlamında önemli etik tartışmalar getirmektedir. Hastanın yararına olduğu düşünülerek olsa da hastaya hastalığı veya hastalığının bundan sonraki seyri hakkında bilgi verilmemesi, eksik bilgi verilmesi ya da yanlış bilgi verilmesi, hastanın sağlık durumu konusunda bilgi sahibi olma, beden bütünlüğü ve geleceği hakkında karar verme, özel hayatına saygı hakları açısından ihlallere neden olabilir $(6,7,8)$.

Hekimler genel olarak hastanın zarar görmemesi adına hastaya gerçeğin söylenmemesi yaklaşımından son dönemlerde uzaklaşmıştır (4). Örneğin 1961 yılında Amerika Birleşik Devletleri'nde yayınlanan bir çalışmada Terminal dönemdeki kanserlerde hastaya gerçeği söyleme konusundaki genel yaklaşımınız nedir? Sorusuna katılımcı hekimlerin sadece yüzde on ikisi hastaya bilgi veririm seklinde cevap vermiştir (9). Hekimler bu yaklaşımda iken 1957 yılında kanser kliniklerinde bekleyen hasta ve yakınları ile yapılan bir çalışmada katılımcıların yüzde seksen yedisi tanının hastaya söylenmesi gerektiği görüşündeydi
(10). Kanserli olmayan bireyler ile yapılan benzer bir çalışmada ise katılımcıların yüzde seksen sekizi tanının söylenmesi gerektiği fikrindeydi (11).

Hekimlerin hastaya gerçeğin söylenmemesi yönündeki tutumlarına karşın 1977 'de yapılan çalışmada hastaya bilgi verilmesi yönünde önemli bir değişiklik görülmüştür (12). Doksanlı yıllardan sonra hastanın tam olarak sağlık durumu hakkında bilgilenme ve tedavisi ile ilgili karar verme hakk1 belirginleşmeye başlamıştır (13).

Hastaya sağlı durumu hakkında gerçeğin söylenmemesi ile ilgili yaklaşımlar kültür, din, etnik köken yasal düzenlemeler gibi nedenlere bağl1 olarak da değişmektedir (14,15). 1990'lı yıllarda Güney ve Doğu Avrupalı hekimlerin, kuzeydekilere göre tanıyı daha fazla saklamak eğiliminde oldukları belirlenmiştir (16). Hastaya sağlık durumu hakkında gerçeğin söylenmemesi bazı kültürlerde yaygındır (5). Doğu ve batı kültürleri arasında bu konuda farklara dikkat çekilmektedir (17). Hastaya tanısı ve sağlık durumu konusunda bilgi verilmemesinin halen Çin'de önemli bir sorun olduğu belirtilmektedir $(17,18)$.

Türkiye'de hastaya gerçeğin söylenmemesi konusunda genel bir eğilimin olduğu bildirilmektedir $(14,19,20)$. Buna karşın yakın tarihli çalışmalar hastaların bilgi almak istediğini göstermektedir $(19,21)$. Türkiye'de hastanın sağlık durumu ile ilgili gerçeğin söylenmemesinin hastanın sağlık durumu ile ilgili bilgi alma ve aydınlatıldıktan sonra tıbbi girişimlere serbest iradesi ile karar verme haklarına aykırı olduğu ileri sürülerek hem tıp etiği hem de hukuk açısından eleştirilmektedir $(22,23,24)$.

\section{Türk Hukukunda Durum}

Hastaya gerçeğin söylenmemesi ile ilgili hükümler Tibbi Deontoloji Nizamnamesi'nin 14'üncü maddesi ile Hasta Hakları Yönetmeliği'nin 19'uncu maddesinde yer almaktadır $(25,26)$. Bu düzenlemeler, hastanın sağlık durumu hakkında bilgilendirilmesini temel alsa da bazı istisnai hallerde hastadan bilginin saklanabileceğini öngörmektedir. $\mathrm{Bu}$ maddelerde, tanının söylenmesinin hastanın maneviyatı üzerinde neden olacağı olumsuz etkinin engellenmesi amacıyla 
bilginin hastadan saklanabileceği belirtilmiştir. Bu yaklaşım ile hastanın teşhis ve teşhise bağlı olarak gerçekleştirilecek girişimler konusunda bilgilendirme zorunluluğunun istisnasına yer verilmiştir.

Hem Tibbi Deontoloji Nizamnamesi'nde hem de Hasta Hakları Yönetmeliği'nde hastanın başkasının bilgilendirilmemesini talep etmediği hallerde hastanın yakınlarının bilgilendirilebileceği belirtilmiştir. Her iki düzenlemeye göre hastadan bilgi saklanıp saklanmaması ve hastanın yakınlarına bilgi verilmesi konusunda inisiyatif hekime bırakılmıştır.

$\mathrm{Bu}$ hükümler, hastanın beden bütünlügü ve geleceği hakkında karar verme ve özel hayatına sayg1 haklarını koruyan yasalara aykırıdır. $\mathrm{Bu}$ hükümlerin uygulanması, bu hakların ihlaline de neden olacaktır. Dahası bu hükümler hekim hasta ilişkisinde güvenin sağlanması açısından da önemli sorunlar içermektedir.

\section{Hastaya Gerçeğin Söylenmemesi ve Hastanın}

\section{Beden Bütünlüğü/Geleceği Hakkında Karar Verme Hakkına Aykırılık}

Hastanın zarar görmemesini sağlamak amacıyla hastaya bilgi verilmeyebileceğini öngören T1bbi Deontoloji Nizamnamesi'nin ve Hasta Hakları Yönetmeliği'nin ilgili hükümleri hastanın beden bütünlüğü ve geleceği hakkında karar verme hakkını koruyan uluslararası sözleşme, Anayasa ve yasalara aykırıdır.

Her bireyin sağlik durumu hakkında bilgi alma hakk1 vardır. Bu hak, bireylere beden bütünlükleri, yaşamları, sağlıkları ve gelecekleri hakkında karar verme hakkını sağlamak üzere tanınmıştır. Her biri birey için büyük önem taşıyan bu hakların sağlanması aslında bireylerin yaşam hakkına saygının da gereğidir. Ayrıca bu bilgilendirilme, bireye gerçekleştirilecek tıbbi girişimlerin ön koşulu olan onamın da geçerli olabilmesi için aranan bir şarttır. Bilgilendirilmeden alınan onamın etik ve yasal açıdan kabul görmeyeceği artık yerleşmiş bir yaklaşımdır. Hatta bu yaklaşım yasalarla da güvenceye alınmıştır $(27,28,2)$.

Türkiye'de bireyin maddi ve manevi varlığını koruyan Anayasa'nın 17'inci maddesi, kanunların öngördüğü haller dışında onamı olmadan bireyin beden bütünlüğüne müdahale edilemeyeceğini öngörmektedir (29,30,31). Türk Medeni Kanunu'nun beden bütünlüğünün korunması, kişilik haklarının dokunulmazlığı ile ilgili 23'üncü maddesine göre, bireyin onamı olmadan bireyin beden bütünlüğüne müdahale edilemez. Türk Ceza Kanunu'nun 26'1nc1 maddesinin 2'inci fikrasına göre kişinin verdiği onam kapsamında gerçekleştirilen fiiller, hukuka aykırı değildir (30) Bu sınırlamalar tıbbi müdahaleler için de geçerlidir. Türkiye'nin taraf olduğu Biyoetik Sözleşmesi (32) ile 1219 Sayılı Tababet Kanunu, tıbbi müdahalelerden önce hastanın onamının alınması zorunluluğu getirmiştir (33). $\mathrm{Bu}$ düzenlemeler kapsamında tedavi amaçlı olan tıbbi girişimlerde dahi (yasaların öngördüğü bazı istisnalar dışında) hastanın onamı olmadan hastanın beden bütünlüğüne müdahale, yasal değildir.

Hastanın tıbbi girişime verdiği onamın geçerli olabilmesi, hastanın sağlik durumu, hastalığının seyri, kendisine gerçekleştirilecek girişim, bu girişimin nedenleri, zararları, riskleri, gerçekleştirilmemesi halinde karşılaşılacak durumlar gibi konularda anlayabileceği şekilde bilgilendirilmesine bağlıdır. Hastanın zarar görmemesi veya hastaya yarar sağlanması beklentisiyle olsa da hastaya bilgi verilmemesi, eksik ya da yanlış bilgi verilmesi tıbbi müdahaleyi yasal hale getiren aydinlatma unsurunu eksik bırakacaktır. $\mathrm{Bu}$ bağlamda gerçekleştirilen girişimler hukuka aykırı olacaktır.

Hastadan bilgi saklanmasi, hastaya bilgi verilmemesi gibi durumlarda hastanın tedavisi için uygulanan tedavi yöntemlerinin amacı, gerekliliği hakkında bilgi verilebilmesi de kolay ya da gerektiği gibi olmayacaktır. Taraf olduğumuz uluslararası sözleşme, Anayasa ve yukarda yer verilen yasaların onam alınmadan tıbbi girişimin geçekleştirilemeyeceği yönündeki hükümlerine rağmen Hasta Hakları Yönetmeliği ve Tıbbi Deontoloji Nizamnamesi'nin hastadan bilginin saklanmasina ya da hastaya bilgi verilmemesine izin vermesi tüzük ve yönetmeliklerin yasaya aykırı olamayacağı, temel hak ve özgürlüklerin yasa ile düzenlenmesi kurallarına aykırıdır.

Hasta Hakları Yönetmeliği ve Tıbbi Deontoloji Nizamnamesi'nde yer alan hükümler, yalnızca 
hastanın bilgi almak istememe hakkını kullanmak istediği sınırlarda uygulanacak şekilde düzenlenmelidir. Başka bir deyişle hastadan bilgi saklanması veya eksik bilgi verilmesi ya da hiç bilgi verilmemesi yalnızca hastanın talep ettiği durumlar ile sinırlanmalıdır.

\section{Gerçeğin Söylenmemesi Yerine Hastanın Bilgilenmeme Hakkına Saygı}

Yakın tarihli çalışmalar ve hatta eski tarihli çalışmalar hastaların sağlık durumları hakkında bilgi edinmek istediklerini göstermektedir. Hastaya gerçeğin söylenmemesinin en çok tartış1ldığ 1 alanlardan biri olan kanserlerde hastalar veya sağlıklı bireyler hastalanmaları halinde sağlı durumları ile ilgili bilgi edinmek istemekte ve hatta bunun anlayacakları şekilde kendilerine aktarılmasını talep etmektedir. Araştırmalara katılan katılımcıların küçük bir oranı hastalığı konusunda bilgi edinmek istemediğini bildirmektedir $(10,11,19,21)$.

\begin{tabular}{clll} 
Gerçeğin & \multicolumn{2}{c}{ söylenmemesi } & \multicolumn{2}{c}{ yaklaşımından } \\
uzaklaş1lırken & sağlık durumu & konusunda \\
bilgilendirilmek & istemeyen & hastalar & göz ard1 \\
edilmemelidir. & Hastanın & serbest & iradesiyle
\end{tabular}
bilgilendirilmekten vazgeçme hakkına sayg1 gösterilmelidir (34). Ancak hastanın bu hakkını kullanabilmesi için hastanın sağlık durumu, kendisine gerçekleştirilebilecek tıbbi girişimler, bunlar hakkında karar verme, onamı olmadan tıbbi girişme tabi tutulmama haklarının olduğu hastaya söylenmiş olmalıdır. Genellikle hastaların bu haklarını bilmedikleri, bu nedenle bu hakları ile ilgili bilgilendirilmeleri gerektiği belirtilmektedir. $\mathrm{Bu}$ konularda verilen bilgilerden sonra hastaya bilgi edinmeme hakkının da bulunduğu söylenebilir. Bilgilendirilmemeyi seçen hasta, bu seçimini serbest iradesi ile yapmalıdır. Hastanın serbest iradesine dayanmayan bir bilgilendirilmeden vazgeçme beyanı geçerli olmaz (28). Bilgilendirilme hakkından vazgeçen hasta, bu konudaki talebini açıkça ifade etmelidir $(35,36)$. Kayıtsız şartsız bilgilendirme isteyen hastaya psikolojik zararlara yol açacak olsa bile bilgilendirme yapılmalıdır (28).

Bilgilendirildikten sonra hastanın onamının alınmasındaki tek amaç, hastanın tıbbi girişime karar verebilmesini sağlamak değildir. Hastanın bilgilendirildikten sonra onamının alınmasının esas amac1, hastanın kişisel seçim yapabilmesidir. $\mathrm{Bu}$ bağlamda hastanın bilgilendirilme hakkından vazgeçmesi, bilgilendirilerek onamının alınması hakkı ile çelişmez. Hasta bilgilendirilme hakkından vazgeçerek, bilgilerin kendisi üzerinde neden olacağı olumsuz etkilerden korunmak isteyebilir (28).

Türkiye'de Hasta Hakları Yönetmeliği'nde hastaya bilgilendirilmekten vaz geçme hakkı tanınmıştır (madde 20). Bu maddeye göre, yasal düzenlemeler veya hastalığın özellikleri gereği, yetkili mercilerin önlem almasını gerektiren bir durum yoksa hasta kendisine veya yakınlarına sağlık durumu ile ilgili bilgi verilmesini istemeyebilir. Hastaya bu hak tanınırken, hastalığın özelliklerinin hastanın bu hakkını kullanmasına engel olabileceği belirtilmiştir. Hastanın hastalığ ve sağlık durumu hakkında bilgi sahibi olmamasının hastanın kendisine veya diğer kişilere zarar verme olasılığının bulunduğu durumlarda hasta bilgilendirilmeme hakkını kullanamayacaktır. Tıp bilimi ve uygulamasına henüz yerleşmemiş tıbbi girişimlerin denenmesi durumlarında, hastanın bilgilendirilme hakkından vaz geçemez. Ayırtım gücü bulunmayan hastanın yasal temsilcisinin de bilgilendirilme hakkından vazgeçemeyeceği savunulur (35). Hasta Hakları Yönetmeliği'nde hastanın bu talebini yazılı olarak belgelemesi beklenmektedir. Aynı maddede hastanın bu talebini dilediği zaman değiştirebileceği de belirtilmiştir.

Bilgilendirilme ve onam verme hakk1 ile ilgili bilgilendirilen, buna rağmen serbest iradesi ile bilgilenme hakkından vazgeçen ve bunu açıç̧a beyan eden hastaya sağlık durumu konusunda bilgi verilmemesi tıp etiği ve hukuku açısından haklı çıkarılabilir. Hastanın bu yönde serbest iradesi ile bir talebi olmadıkça hastadan bilgi saklanmasının, hastaya bilgi verilmemesinin tıp hukuku ve etiği açısından haklı çıkarılması güçtür.

Kendilerine herhangi bir tedavi uygulanmayacak yalnızca bakım sağlanacak hastalara da bilgi verilmemesi hastaların bilgilenme ve gelecekleri hakkında karar verme haklarına aykırılık oluşturmaktadır. $\mathrm{Bu}$ hastaların yaşamlarının son dönemi, malvarlıkları gibi önemli kişisel konularda karar verme hakkı olduğu kabul edilmelidir. 


\section{Gerçeğin Söylenmemesi ve Hastanın Özel Hayatına Saygı Hakkı}

Hastadan bilgi saklanmasının ya da hastaya bilgi verilmemesinin neden olabileceği bir diğer hak ihlali de hastanın özel yaşam hakkının ihlalidir (6). Kişinin sağlık durumu ile ilgili bilgilerin özel yaşamının önemli bir alanını oluşturduğu, bunlar ile ilgili bilgilerin gizli kalmasının esas olduğu hem uluslararas1 belgelerde hem yasalarda kabul edilmektedir. $\mathrm{Bu}$ bağlamda bu hakkın sinırlı hallerde göz ardı edileceği de belirtilmektedir. Genellikle kamunun ya da başka kişilerin zarar görme olasılıklarının yüksek olduğu durumlarda, yarg1 taleplerinde bu bilgilerin başka kişi ya da kurumlar ile paylaşılabileceği kabul edilmektedir. Bunun dışındaki durumlarda bilgilerin gizli kalması açıklanmaması beklenmektedir. Bu bilgiler, sadece hastaların istediği sınırlarda ve kişiler ile paylaşılabilir.

Hastanın olumsuz etkileneceği düşünülerek hastaya bilgi verilmeyeceği durumlarda hastadan başka birinin bilgilendirilmesi gerekmektedir. Hatta özellikle kanserle yaşayan hastalara tanının söylenmemesi ile ilgili çalışmalarda hasta yakınlarının bu konudaki önemli rollerine önemle vurgu yapılmaktadır $(18,19)$. Hastanın yakınları, hastalarının bilgilendirilmemesini, hasta yerine bilgilerin kendilerine aktarılmasını talep etmektedir. Yapılan çalışmalar Türkiye'de hekimlerin tanıyı hastadan gizleme eğiliminde olduklarını ve genellikle bir yakına tanının söylendiğini göstermektedir (37). Hastalar genellikle yakınlarının bilgilendirilmesini istemektedir. Ancak önemsenmesi gereken oranlarda hasta da yakınlarına bilgi verilmesini istememektedir. Türkiye'de yapılan bir çalışmada, hastaların yüzde doksana yakın kısmı yakının da bilgilendirilmesini uygun bulmuşken yüzde onundan fazlası yakınına bilgi verilmemesini istemiştir (21). Buradaki oranlar hastanın kendisi ile beraber yakının da bilgilendirilmesini istediği oranlardır. Hastaya bilgi verilmeden hastanın yakınına bilgi verilmesini istediği oranı göstermemektedir.

Türkiye'de hem Trbbi Deontoloji Nizamnamesi hem de Hasta Hakları Yönetmeliği, hekimin "başkalarına bilgi verilmemesini talep etmeyen hastanı" yakınlarına bilgi verebileceğini öngörmektedir. Oysa başta Anayasa olmak üzere pek çok yasa ve diğer yasal düzenlemede bireylerin özel yaşam hakkı korunmaktadır. Hatta Kişisel Verilerin Korunması Kanunu kapsamında işinin sağlık durumu ile ilgili bilgiler özel nitelikte kişisel veriler olarak kabul edilmiş ve kişinin açık onamı olmadan paylaşılamayacağ 1 belirtilmiştir (38). Bu şekilde bir paylaşım öncelikle Kişisel Verilerin Korunması Kanunu'na aykırı olacaktır. Yasa ile korunan bir kişilik hakkının Tıbbi Deontoloji Nizamnamesi ile ya da Hasta Hakları Yönetmeliği ile sınırlanması Anayasanın kişilik haklarının yalnızca yasa ile sınırlanabileceği hükmüne aykırıdır.

Hastadan başkasının bilgilendirilmesi ile ilgili olarak da hastanın beklenti ve taleplerine öncelik verilmelidir. Hasta Hakları Yönetmeliği'nde başkasının bilgilendirilmesini talep hakkı hastaya tanınmıştır (madde 18/3). Hasta Hakları Yönetmeliği'nde hastanın bu talebini yazılı yapması beklenmektedir. Başkasının bilgilendirilmesini talep eden hastaya da kendisinin bilgilendirilme hakkının öncelikli olduğu, kendisi izin vermediği sürece bilgilerinin kimse ile paylaşılmayacağ konularında bilgi verilmelidir. Bundan sonra hastanın başkasının bilgilendirilmesi yönünde bir talebi olursa bu talep, kabul edilmelidir. Ayrıca hastanın başkalarının bilgilendirilmesi konusunda sınırları belirleme hakkı vardır. Bu bağlamda, hasta belli kişilerin belli konularda bilgilendirilmesi ile ilgili sinırlar koyabilir. $\mathrm{Bu}$ sinırlara da uygun hareket edilmelidir. Hastanın başkasının bilgilendirilmesi ile ilgili talebi de hastanın serbest iradesine dayanmalıdır.

Hasta Hakları Yönetmeliği'ne göre, hastanın kendisine bilgi verilmesini yasaklayabileceği gibi yakınlarının hatta hiç kimsenin bilgilendirilmemesini talep edebilir (madde 20). Bu madde ile ilgili bir konunun açıklığa kavuşturulması önemlidir. Önceden de belirtildiği gibi gerek Anaysa gerekse yasa düzeyinde pek çok düzenleme ve taraf olduğumuz uluslararası sözleşme ile hasta hakları bildirgeleri, hastanın özel hayatının gizliliği kapsamında bilgilerinin yasaların izin verdiği durumlar dişında kimse ile paylaşılamayacağını öngörmektedir (1). Buna göre Hasta Hakları Yönetmeliği'nde hastanın yakınlarının bilgilendirilmesini yasaklamasına yer 
verilmesine gerek yoktur. Bu şekilde bir maddeye yer verilmesi, hastanın başkasına bilgi verilmesini yasaklamadığı sürece bu bilgilerin başkalarına açıklanabileceği sonucunun çıkarılmasına neden olabilir. $\mathrm{Bu}$ maddenin hastanın kendisine bilgi verilmesini istemediği durumlar ile sınırlandırılmalıdır. Hastanın başka kişilerin bilgilendirilmesi ile ilgili düzenleme Hasta Hakları Yönetmeliği'nin 18'inci maddesinde zaten yer almaktadır.

\section{Hastanın Bilgilendirmeyi Yetkin Olmayan Kişiden Alma Olasılığı}

Hastanın sağlık durumu konusunda hekim tarafindan bilgilendirilmesi önemlidir. Yapılan çalışmalarda kişilerin kanser ile ilgili olarak tanıyı koyan ya da tedavi eden hekim tarafindan bilgilendirilmek istediğini ortaya koymaktadır (19). Hastalara gerçeğin söylenmesi hastanın özerkliği, geleceği hakkında karar alma hakları açısından önem taşıdığı gibi hekim - hasta arasında olması gereken güven ilişkisi için büyük önem taşımaktadır (39). Hastanın sağlık durumu ile ilgili bilginin hasta ile paylaşıldığ durumlarda hasta ile sağlık çalışanı arasında kurulacak dürüstlük ilişkisinin bilginin hasta ile paylaşılmadığ durumlardan çok daha ileri seviyelerde olacağına özellikle işaret edilmektedir (34). Bu çerçevede hastaya gerçeğin söylenmesi hekim-hasta ilişkisinde dürüstlük ve güven ilişkisini sağlama açısından da gereklidir. Hekimden beklenen dürüstlük ve hekime duyulan güven hekimin hastayı zarardan korumasını gerektirir. Hekimin hastaya gerçeği söylememesi hastaya bazı koşullarda zarar da verebilecektir. Örneğin hekimin hastaya sağlik durumu ile ilgili gerçeği söylememesi, hastanın konu ile ilgili bilgi veya uzmanlığ 1 olmayan kişiler tarafindan bilgilendirilmesi riskini de içerir. Başkalarının hastanın sağlık durumu ile ilgili bilgi sahibi olduğu bazı durumlarda, bu kişilerin duyarsız bir şekilde hastaya durumu konusunda bilgi vermeleri söz konusu olabilecektir. Benzer olarak tanısı söylenmemiş ya da sağlık durumu hakkında gerçeği öğrenememiş bir hastanın sağlık durumu ile ilgili kuşkularını kendi çabasıyla gidermeye çalışması sonucunda gerçeği öğrenebilir (41). Bu bağlamda günümüzde bireylerin bilgiye erişimi ile ilgili olanaklar göz önünde bulundurulduğunda hastanın kendisinden gizlenen veya söylenmeyen gerçeğe çoğu zaman ulaşma imkanının olduğu göz önünde tutulmalıdır. $\mathrm{Bu}$ bağlamda hastaya gerçeğin söylenmemesinin nedenlerinden biri olan zararın önüne geçilmesi kolay olmayacaktır. Her iki durumda da hastanın psikolojik açıdan daha ağır bir zararla karşılaşması mümkündür. Mesleki etik ve deontoloji kuralları ile hareket etme ödevi ve mesleki duyarlılı̆g olan hekimin hastay1 bilgilendirmesi çok daha yararlı olacak ve hastanın daha az zarar görmesini sağlayacaktır (40).

\section{SONUÇ}

Türk hukukunda hastanın zarar görmemesi ve hastaya yarar sağlanması amacıyla hastaya gerçeğin söylenmemesini öngören hükümler T1bbi Deontoloji Nizamnamesi'nde ve Hasta Hakları Yönetmeliği'nde yer almaktadır. Bu hükümlere dayanılarak hastaların sağlık durumları hakkında bilgilendirilmemesi ya da eksik bilgilendirilmesi hastanın beden bütünlüğü ve geleceği hakkında karar verme haklarının ihlaline neden olabilir. Hastanın tıbbi girişimden önce bilgilendirilmesi ve bu bilgilendirmeye dayanarak onamının alınmas1, günümüzde tıbbi girişimin hukuka ve etiğe uygun bir girişim olarak kabul edilmesi için temel bir şarttır. Türkiye'de Biyoetik Sözleşmesi, Anayasa ve yukarıda yer verilen diğer yasalar, onam alınmadan hastaya tıbbi girişimin gerçekleştirilemeyeceğini öngörmektedir. Hastadan bilgi saklanması, hastaya bilgi verilmemesi gibi durumlarda, hastadan alınan onam geçerli olmayacaktır. Buna rağmen Hasta Hakları Yönetmeliği ve Tibbi Deontoloji Nizamnamesi'nin hastadan bilginin saklanmasına ya da hastaya bilgi verilmemesine izin vermesi tüzük ve yönetmeliklerin yasaya aykırı olamayacağı, temel hak ve özgürlüklerin yasa ile düzenlenmesi kurallarına aykırıdır. Bu hükümler, yalnızca hastanın bilgi almak istememe hakkını kullanmak istediği sınırlarda uygulanacak şekilde yeniden düzenlenmelidir.

Türkiye'de hem Trbbi Deontoloji Nizamnamesi hem de Hasta Hakları Yönetmeliği, hekimin "başkalarına bilgi verilmemesini talep etmeyen hastanın" yakınlarına bilgi verebileceğini 
öngörmektedir. Bu hükümler, bireylerin özel yaşam hakkını koruyan başta Anayasa olmak üzere pek çok yasa ve diğer yasal düzenlemelere aykırıdır. Anayasa ve diğer yasalarda korunan özel hayatın gizliliğine saygı hakkına aykırı hükümlerin Tıbbi Deontoloji Nizamnamesi ya da Hasta Hakları Yönetmeliği'nde yer alması Anayasa'nın kişilik haklarının yalnızca yasa ile sınırlanabileceği hükmüne aykırıdır. $\mathrm{Bu}$ düzenlemeler yerine hastadan başkasının bilgilendirilmesi konusunda yalnızca hastanın beklenti ve taleplerine uygun yaklaşımlara yer veren hükümler getirilmelidir.

Hastadan gerçeğin saklanmasına izin veren bu düzenlemelerin getireceği bir diğer sakınca da hastanın gerçeği yetkin olmayan kişilerden ya da kendi çabası ile öğrenmesi durumunda yaşayabileceği olumsuzluklardır. $\mathrm{Bu}$ gibi durumlarla karşılaşılmaması için mesleki etik ve deontolojik kurallar bağlamında hareket etmekle yükümlü olan hekimin hastayı bilgilendirmesi önemlidir.

Hastaya gerçeğin söylenmemesi ile önlenmek istenen zarar ve sağlanmak istenen yarar için hekim ve hastayı desteleyecek tedbirlerin alınması, gerçeğin söylenmesinin getireceği sakıncaları azaltan koşulların sağlanması bireyin özerkliğine, hekim hasta ilişkisindeki güven ve dürüstlüğe aykırı olan gerçeğin söylenmemesini önleyecektir. Hastanın zarar görmemesi amaciyla hastaya gerçeğin söylenmemesine olanak tanıyan hükümler, hem günümüz hekim hasta ilişkisinde kabul gören hastanın özerkliğine saygılı anlayışa hem de yasalara aykırı olmaları nedeniyle kaldırılmalıdır. $\mathrm{Bu}$ hükümlerin yerine hastanın talep ve beklentilerine uygun, hastanın iradesini ve özerkliğini temel alan hükümlere yer verilmelidir.

\section{KAYNAKLAR}

1. Sert G. Uluslararası bildirgeler ve tıp etiği açısından hasta hakları. Seçkin Hukuk Yayınları, Güncellenmiş 2. Bask1, Ankara, 2019. s.135, 136,58,64,75,87

2. Jonsenar, Siegler M, Winslade Wj. Clinical Ethics: a practical aproach to ethical decisions in clinical medicine, Seventh Edition Mc Graw Hill Medical, Publishing, 2010. s. 51.
3. Jackson J. Telling the truth. Journal of Medical Ethics, 1991; 17: 5-9

4. Veatch RM, The Basics of Bioethics. 2nd ed. Prentice Hall, New Jersey 2003. pp.80

5. Ethical issues in death and dying, second edition, Ed. Beauchamp Tl. / Veatch Rm. Prentice hall new-jersey 1996. pp 65.

6. Higgs R. On telling patients truth. Moral dilemmas in medicine Ed. Lockwood M, 192-202, Oxford OUP. 1985. s. 192-202.

7. Rogers W, Mayer AB. Practical Ethics for General Practice. Oxford, 2004. . s. 45-53

8. Annas, GJ. Rights of the terminally 11 patient. Journal of Nursing Administration 1974 March-April: s. 40-44.

9. Oken D. What to tell cancer patients a study of medical attitudes. Journal of American Medical Association April 1, 1961: 1120-1128.

10. Samp R J, Curreri A R. A questionnaire survey on public cancer education obtained from cancer patients and their families Cancer 1957: 10. 384-382.

11. Hardin $\mathrm{CH}$. Branch physiciatric aspects of malignant disease. Bulltein of Cancer Progress 1956; 6:102-104.

12. Novack DH, Plumer R, Smith RL, Ochitill H, Morrow GR, Bennett JM. changes in physicians' attitudes toward telling the cancer patient. Journal of the American Medical Association 1979;241(9):897-900

13. Goldberg Rj. Disclosure of information to adult cancer patients: issues update. J Clin Oncol 1984;2: 948-54.

14. Balseven A, Büken Örnek N. Yaşamın sonunda alınan kararlarda hekimin tutumu kültürlerarası karşılaştırma. Klinik, Etik, Kültürel ve Hukuki Yönleriyle Yaşamın Sonuna İlişkin Kararlar Toplantısı. Ed. Büken Örnek N, Akpınar A. Hacettepe Biyoetik Merkezi Hacettepe Üniversitesi Matbaası. Ankara 2014; 48-54.

15. Rosenberg AR, Starks H, Unguru $Y$, Feudtne C, Diekema D, Truth telling in the setting of cultural differences and incurable pediatric illness. JAMA Pediatr. 2017 Nov 1; 171(11): 11131119.

16. Thomsen OO, Wulff Hr, Martin A, Singer PA. What Do Gastroenterologists In Europe Tell 
Cancer Patients? Lancet. 1993 Feb; 20;341(8843):473-6.

17. Liu Y, Yang J, Huo D, Fan H, Gao Y. Disclosure of cancer diagnosis in China: the incidence, patients' situation, and different preferences between patients and their family members and related influence factors. Cancer Management and Research 2018; 10:2173-2181

18. Ni YH, Alraek T. What circumstances lead to non-disclosure of cancer-related information in China? A qualitative study Support Care Cancer 2017; 25:811-816

19. Datlı U, Çelik P, Gökaltay T, Şakar Coşkun A, Yorgancioğlu AA. Hekimlerin, hasta yakınlarının ve toplumun akciğer kanseri tanısının söylenmesine ilişkin görüşlerinin değerlendirilmesi. Tuberk Toraks 2017; 65 (1):9-17.

20. Ozdogan M, Samur M, Bozcuk HS, Coban E, Artac M, Savas B, et al. "Do not tell": what factors affect relatives' attitudes to honest disclosure of diagnosis to cancer patients? Support Care Cancer 2004; 12:497-502.

21. Yıldırım G. Sağlık hukuku açısından kanserli hastaları bilgilendirme zorunluluğu ve bilgilendirmenin psikolojik sonuçları T.C. Medipol Üniversitesi Sosyal Bilimler Enstitüsü Sağlık Hukuku Anabilim Dalı, Doktora Tezi, Danışman Gönenç Fİ.

22. Erdem A. Hasta Hakları ve Terminal Dönem. Yoğun Bakım Dergisi 2003;3(1):37-42

23. Köprülü Ö. Hekimin Hukuki Sorumluluğu. İBD 1984; 58 (10-11-12):589-613.

24. Reisoğlu S. Hekimlerin Hukuki Sorumluluğu. Sorumluluk hukukundaki yeni gelişmeler v. sempozyumu, Türk hukukunda hekimin hukuki ve cezai sorumluluğu, Ankara 1213 Mart 1982, 1983.

25. Tibbi Deontoloji Nizamnamesi. 4/12578 Bakanlar Kurulu Kararı, RG: T. 19.2.1960, S. 10436.

26. Hasta Hakları Yönetmeliği. RG: T. 01.08.1998, S. 23420

27. Beachamp TL. Informed consent, in medical ethics ed. Veatch RM, jones and bartlett publishers, inc.:1989;173-200.

28. Appelbaum PS, Lidz CW, Meisel A. Informed Consent Legal and Clinical Practise. New
York Oxford University Press, USA, 1987. .s. $13,66-71,79$

29. Helvacı, S. Türk ve İsviçre Hukuklarında Kişilik Haklarını Koruyucu Davalar, (Mk. D. 24/a fikra I, İMK md. 28/a fikra I), Beta, İstanbul, 2001. s.52

30. Erman, B. Tibbi Müdahalenin Hukuka Uygunluğu, Birinci Baskı, Seçkin Yayınları, Ankara, 2003, s.154;

31. Ozanoğlu HS. Hekimlerin Hastalarını Aydınlatma Yükümlülüğü, AÜ-HFD, 2003,Cilt 52, Sayı:3, Ankara, s.55-77, s.60.

32. "Biyoloji ve Tibbın Uygulanmas1 Bakımından İnsan Hakları ve İnsan Haysiyetinin Korunması Sözleşmesi: İnsan Hakları ve Biyotıp Sözleşmesi” Avrupa Konseyi bünyesinde 4 Nisan 1997 tarihinde imzaya açılmış, Türkiye Cumhuriyeti tarafindan, 4 Nisan 1997 tarihinde imzalanan bu Sözleşme; TBMM tarafindan 3.12.2003 tarihinde onaylanmıştır. Bu sözleşmenin onaylandığına dair kanun, 5013 Kanun numarası ile 9 Aralık 2003 tarihli ve 25311 sayılı Resmi Gazete'de yayımlanarak aynı tarihte yürürlüğe girmiştir.

33. Tababet ve Şuabat-1 Sanatlarının Tarz-1 İcrasına Dair Kanun. RG: T. 1928, S.863.

34. Storch, J. Patients' rights ethical and legal 1ssues in health care and nursing, McGraw-Hill Ryerson Limited, Canada 1982. s. 57

35. Ayan M. T1bbi Müdahaleden Doğan Hukuki Sorumluluk, Kazancı Yayınları, İstanbul, 1993. s.78-79

36. Aşçı̆ı̆lu Ç. Tıbbi yardım ve el atmalardan doğan sorumluluklar, doktorların devletin ve özel hastanelerin sorumluluğu, cezai ve hukuki, Ankara, 1993. s.34

37. Doruk S, Sevinç C, Fidan Sever, İtil O, Akkoçlu A. The trends of relevance about telling lung cancer diagnosis: social constraints, medical practice in several clinics Tuberk Toraks 2012; 60(4): 336-343

38. Kişisel Verilerin Korunması Kanunu. RG: T. 7 Nisan 2016, S. 29677

39. Büken, Örnek Nu. Truth Telling İnformation Communication With Cancer Patients İn Turkey JSHIM 2003;2:31-36.

40. Sert, G. Tip Etiği Ve Mahremiyet Hakkı, Babil Yayınları, İstanbul, 2008. s. 134,135 
41. Ateşçi, FÇ, Oğuzhanoğlu NK, Baltalarlı B.

Karadağ F. Özdel O. Karagöz N. Kanser

Hastalarında Psikiyatrik Bozukluklar Ve İlişkili

Etmenler. Türk Psikiyatri Derg; 2003;14: 145-152. 